\title{
Sieved Transport and Redistribution of Bioavailable Phosphorus from Watershed with Complex River Networks to Lake
}

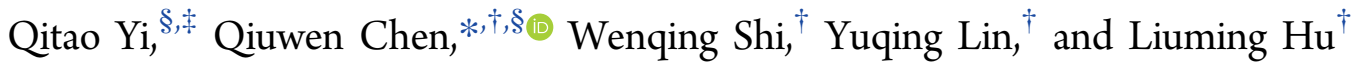 \\ ${ }^{\dagger}$ Center for Eco-Environmental Research, Nanjing Hydraulic Research Institute, Nanjing 210098, China \\ ${ }^{\S}$ Research Center for Eco-Environmental Sciences, Chinese Academy of Sciences, Beijing 100085, China \\ ${ }^{\ddagger}$ School of Earth and Environment, Anhui University of Science and Technology, Huainan 232001, China
}

\section{Supporting Information}

\begin{abstract}
An innovative approach was developed to reveal phosphorus (P) transport and redistribution in large and complex river networks in the Lake Taihu basin by establishing the relations between sediment $\mathrm{P}$ spatial distribution and $\mathrm{P}$ sorption behavior on particles with different grain size, sorted by hydrodynamics. The sediment $\mathrm{P}$ fractionation composition changed greatly across the basin, where $69 \%$ consisted of acidsoluble fractions ( $\mathrm{HCl}-\mathrm{P})$ in upstream rivers while $70 \%$ was in fractions associated with reducible metal hydroxides (BD-P) and amorphous hydroxides $\left(\mathrm{NaOH}_{25}-\mathrm{P}\right)$ in downstream rivers. Fine particles enriched in $\mathrm{BD}-\mathrm{P}$ and $\mathrm{NaOH}_{25}-\mathrm{P}$ fractions tended to sorb liberated $\mathrm{P}$ during the resuspension process, and fine particles were more easily delivered downstream toward the lake, forming a sieved transport of $\mathrm{P}$ in the river networks. This will lead to a great potential for sediment $\mathrm{P}$ release when environmental anoxia develops in the sediments or high $\mathrm{pH}$ occurs in the sediment surface during intensive algal blooms in the shallow lake. Reduction of external P from point sources from urbanized areas is an important requirement at the basin scale; however, long-term efforts are needed to restore aquatic macrophytes in the lake, which would decrease P recycling rates at the water-sediment interface.
\end{abstract}

\section{INTRODUCTION}

Phosphorus (P) is essential to all life (e.g., plants, animals, and bacteria) and is a key ingredient in fertilizers to sustain high crop production. Humans dug up geological phosphate reserves to produce fertilizers to feed the Green Revolution, creating a large one-way flow of phosphorus from rocks to farms to lakes and oceans, dramatically impairing freshwater and coastal marine ecosystems. ${ }^{1}$ The $\mathrm{P}$ cycle is largely related to the physical, chemical, and biological processes activated at the interface between sediment and water; thus, the clarification of these processes is vital for the development of effective $P$ management strategies for restoring the ecosystem in eutrophic water bodies.

Phosphorus activity (mobilization or immobilization) is determined by the behaviors of three types of compounds, iron $(\mathrm{Fe})$, aluminum $(\mathrm{Al})$, and calcite $(\mathrm{Ca})$. Anoxia can enhance $\mathrm{P}$ release from sediment $\mathrm{Fe}-(\mathrm{hydr})$ oxides. $^{2-5}$ Elevated concentrations of $\mathrm{Al}(\mathrm{OH})_{3}$ in the noncalcareous sediments of low-pH lakes can prevent $\mathrm{P}$ release by adsorbing $\mathrm{P}$ liberated from $\mathrm{Fe}$ hydroxides due to the high sorption capacity and stability of $\mathrm{Al}(\mathrm{OH})_{3}$ under both oxic and anoxic conditions. ${ }^{6-9}$ Phosphorus sorption capacity has been linked with calcium carbonate and ferric hydroxide in high-pH lakes. ${ }^{7,10,11}$ Therefore, changes in environmental conditions, such as redox potential, $\mathrm{pH}$ values, or $\mathrm{CO}_{2}$ concentrations, could result in $\mathrm{P}$ mobilization or immobilization from the sediment surface by impacting the above-mentioned biogeochemical processes.

Links between $\mathrm{P}$ discharge, transport, and sedimentation need to be established for $\mathrm{P}$ management practices at the basin scale. This is challenging in hybrid areas containing both urbanization and agriculture, with multiple sources of pollutants. ${ }^{12,13}$ The problem is intensified where complex river networks are concerned, where the complicated flow regime makes $\mathrm{P}$ transport hard to clarify. Although many studies have addressed the impacts of sediment disturbance on $\mathrm{P}$ behaviors in shallow lakes, ${ }^{14-18}$ the understanding of the transport processes between sources and sinks linked through river networks is not sufficient to support $\mathrm{P}$ management at the basin scale. In particular, frequent resuspension of sediments creates a changeable redox environment; ${ }^{15,18,19}$ this could result in $\mathrm{P}$ redistribution on particles with size differences or fractional composition, impacting transport toward downstream and lakes.

The main objectives of this work are to (1) characterize the spatial distribution and fractionation of sediment $\mathrm{P}$ in complex river networks with multiple pollution sources at the basin

Received: May 25, 2017

Revised: August 15, 2017

Accepted: August 25, 2017

Published: August 25, 2017 
scale, (2) clarify P transport potential and discuss the related processes in canals under strong hydrodynamic disturbance of sediments, and (3) reinspect the effectiveness of $P$ management regarding restoration of eutrophic lakes.

\section{MATERIALS AND METHODS}

Study Area. Lake Taihu is the third largest freshwater lake in China, with an area of $2338 \mathrm{~km}^{2}$, an average depth of $1.9 \mathrm{~m}$, and a corresponding volume of 4.4 billion $\mathrm{m}^{3}$. The Lake Taihu basin has an area of approximately $36895 \mathrm{~km}^{2}$ and is located in the Yangtze River delta, the most developed region in China (Figure 1). The main rivers of the networks have been shaped

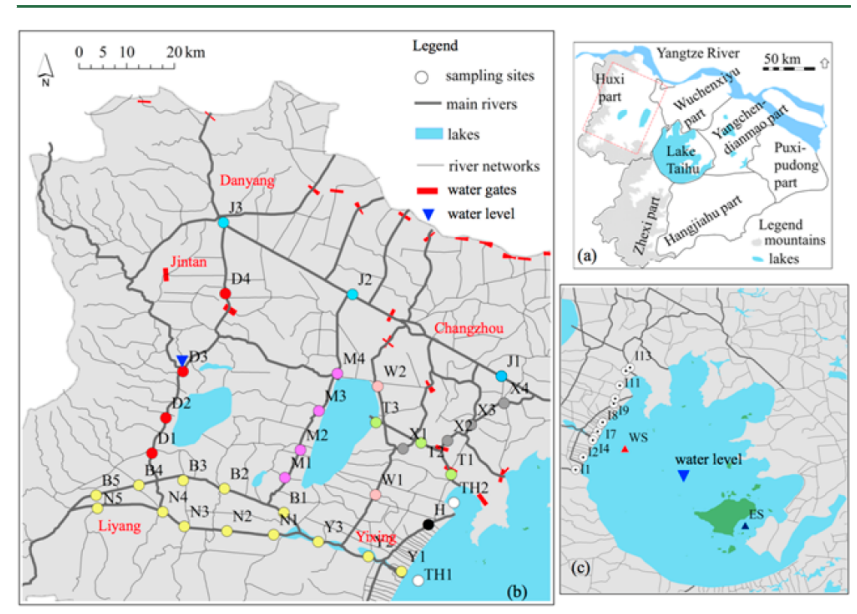

Figure 1. Study areas (a), sampling sites in the inflowing river networks (b), and 13 concentrated inflowing river mouths and sediment core sites of Lake Taihu (c). (Note: the river network is simplified from more complex rivers.)

to form man-made canals serving navigation, flood control, and ecological functions, with numerous hydraulic works regulating water exchange between Lake Taihu and the Yangtze River. More details on climate, topography, and hydrology can be found in a related reference. ${ }^{20}$

The Lake Taihu basin is divided into eight parts (subwatersheds) in terms of hydrological and hydraulic characteristics (Figure 1a), featured by complex plain river networks. This study focuses on the Huxi part, the main drainage areas located in the northwest of the basin, occupying an area of $7791 \mathrm{~km}^{2}$ and discharging $70 \%\left(74.3 \times 10^{8} \mathrm{~m}^{3}\right.$ out of $105.6 \times 10^{8} \mathrm{~m}^{3}$ in 2014) of the total inflow to Lake Taihu (Table S1 in the SI). The flow regime of the river networks is complex, mainly controlled by hydrological conditions and a large number of water gates. Hydrological and flow regimes during the research period of 2014 and 2015-2016 are provided in Figures S1 and S2 in the SI and ref 20. Hydrodynamic disturbance in the main rivers is strong and frequent due to busy canal transportation between cities, causing sediment resuspension with turbid water, as shown in a typical scene in Photo S1 in the SI. Considering the topography, flow direction, and land use together, we defined upstream, midstream, and downstream with the Danjinlicaohe River (D1-D4), the Menginhe River (M1-M4), and the concentrated inflowing rivers (I1-I13) in the north-south direction as the boundaries (Figure $1 \mathrm{~b}$ and $1 \mathrm{c}$ and Table S2 in the SI). The Huxi part is the most heavily polluted area, which contributed the most to water quality deterioration and eutrophication in Lake Taihu. The details of land use related to water quality in this area can be found in the related references. ${ }^{13,20}$

Sampling Design. Sampling campaigns covered the scale from basin to lake, including 37 sites in the main rivers, 13 sites in the concentrated inflowing river mouths surrounding Lake Taihu, and 2 sites in the lake. Specific information concerning sampling sites is listed in Table S1 in the Supporting Information. Four sampling campaigns were conducted across the seasons, with collections occurring in January (winter), April (spring), June (summer), and October (fall) of 2014. Surface water samples were collected in all seasons, but surface sediments were collected only in January of 2014. In addition, monthly sampling campaigns from June 2015 to April 2016 were conducted in the 13 concentrated inflowing river mouths to obtain details on P loading patterns toward the lake. In April of 2015, one more sampling campaign was conducted to obtain sediment cores at two sites, located in the west and east parts of the lake, respectively (Figure 1c), for analyzing $\mathrm{P}$ accumulation in different lake areas and its links with river transport processes. The west part is the concentrated inflow area of Lake Taihu, dominated by microalgae with sporadic aquatic macrophytes. The east part is the concentrated outflow area of the lake, dominated by aquatic vegetation. The west part and east part represent two typical states in the eutrophic lake.

Water Sampling and Analysis. Water samples were taken at $0.5-1.0 \mathrm{~m}$ depth under the surface using a $5 \mathrm{~L}$ Plexiglas water sampler in each site. Temperatures, $\mathrm{pH}$, dissolved oxygen, and electrical conductivity were read on-site using portable YSI electrodes (Xylem Co. New York, USA). The water samples were stored in an icebox, brought to the laboratory, and analyzed immediately. Water parameters, including total suspended solids, total phosphorus, soluble reactive phosphate, and total nitrogen, were analyzed according to Standard Methods. ${ }^{21}$ A detailed description of specific methods is presented in the SI. In addition, the total suspended solids in water samples collected in the winter of 2014 were settled and concentrated for analysis of the particle sizes using a laser particle size analyzer (Mastersizer 2000, Malvern Co., U.K.).

Sediment Sampling, Separation, and Analysis. Surface sediment samples in the river networks were collected using a Peterson gravity sampler. Undisturbed sediment cores, at the west site and east site of the lake, were sampled using a gravity corer and vertically sliced into 20 subsamples on-site, breaking each core into $1 \mathrm{~cm}$ increments from top (at the sedimentwater interface) to bottom (at depth). All sediment samples were directly stored in air-sealed plastic bags and transported to the lab in a portable freezer. Site J2 in the Beijing-Hangzhou Great Canal, where sediment experienced repetitive suspension and sedimentation due to strong hydrodynamic disturbance by ship propellers, was selected as a representative site to analyze $\mathrm{P}$ fractionation and adsorption behavior as a function of particle size distribution. Details about the particle separation column are given in Figure S3 in the SI. Five size groups of particles were obtained in this research, in ranges of " $<5 \mu \mathrm{m}$ ", "5-10 $\mu \mathrm{m}$ ", " $10-30 \mu \mathrm{m}$ ", " $30-50 \mu \mathrm{m}$ ", and " $50-150 \mu \mathrm{m}$ ".

Sediment samples were air dried at room temperature, homogenized, and sieved through a stainless-steel sieve with a mesh size of $150 \mu \mathrm{m}$ and then stored in the dark for further analysis of oxidizable matter and $\mathrm{P}$ fractional composition. The oxidizable matter $(\mathrm{OM})$ was colorimetrically determined after treatment of the sample with chromic acid $/ \mathrm{H}_{2} \mathrm{SO}_{4}$ according to the Walkey-Black method. ${ }^{22}$ Sequential extraction was 
performed on $0.5 \mathrm{~g}$ of air-dried sediment to determine the operationally defined $\mathrm{P}$ fractions using the method proposed by Psenner et al. ${ }^{23}$ with slight modifications suggested by Hupfer et al. $^{24}$ Phosphorus in sediments was extracted sequentially using $1 \mathrm{M} \mathrm{NH}_{4} \mathrm{Cl}, 0.11 \mathrm{M}$ bicarbonate-dithionite (BD), and 1 $\mathrm{M}$ sodium hydroxide $(\mathrm{NaOH})$ at $25{ }^{\circ} \mathrm{C}$ and $0.5 \mathrm{M} \mathrm{HCl}$ and 1 $\mathrm{M} \mathrm{NaOH}$ at $85{ }^{\circ} \mathrm{C}^{7,25,26}$ The resulting fractions were considered as environmental indicators of $\mathrm{P}$ in ion-exchangeable forms $\left(\mathrm{NH}_{4} \mathrm{Cl}-\mathrm{P}\right), \mathrm{P}$ fractions associated with reducible metal hydroxides (BD-P) and amorphous hydroxides $\left(\mathrm{NaOH}_{25}-\mathrm{P}\right)$, acid-soluble $\mathrm{P}$ ( $\left.\mathrm{HCl}-\mathrm{P}\right)$, and residual $\mathrm{P}$ fractions $\left(\mathrm{NaOH}_{85}-\mathrm{P}\right)$. The extracted $\mathrm{P}$ was determined by the molybdenum blue/ascorbic acid method. Total extractable $\mathrm{P}$ (Ext-TP) is the sum of the P measured in all extracted fractions.

Adsorption Isotherms and Sorption Kinetics of Phosphorus. The details of the experiments on the adsorption isotherms and sorption kinetics of $\mathrm{P}$ are provided in the SI. Mathematical descriptions of the adsorption isotherms were obtained by fitting the data sets with linear functions: $Q_{e}=$ $k_{\mathrm{e}} E P C$ - NAP, where $\mathrm{Q}_{\mathrm{e}}$ is the amount of sorbed $\mathrm{P}$ at equilibrium $\left(\mathrm{mg} \mathrm{kg}^{-1}\right)$ and $E P C$ is the equilibrium $\mathrm{P}$ concentration $\left(\mathrm{mg} \mathrm{L}^{-1}\right)$. The factor $k_{\mathrm{e}}$ (slope, $\mathrm{L} \mathrm{kg}^{-1}$ ) is the P-binding energy constant and reflects sorption affinity, and NAP (intercept, $\mathrm{mg} \mathrm{kg}^{-1}$ ) is the native adsorbed $\mathrm{P}^{27}$ The equilibrium $\mathrm{P}$ concentration at zero sorption $\left(E P C_{0}, \mathrm{mg} \mathrm{L}^{-1}\right)$ is a measure of the $\mathrm{P}$ concentration at which sediment is neither adsorbing nor desorbing $\mathrm{P}$ in the equilibrium state. Greater values of $k_{\mathrm{e}}$ and smaller values of $E P C_{0}$ indicate stronger $\mathrm{P}$ sorption ability on sediments and weaker potential for sediment $\mathrm{P}$ release. ${ }^{28}$ Mathematical descriptions of the sorption kinetics were established by fitting the data sets with first order Lagergren sorption functions: $Q_{t}=Q_{e}\left(1-\exp \left(-k_{1} t\right)\right)$, where $Q_{t}$ is the amount of sorbed $P\left(\mathrm{mg} \mathrm{kg}^{-1}\right)$ at time $t(\mathrm{~h}), Q_{\mathrm{e}}$ is the amount of sorbed $\mathrm{P}$ in the equilibrium state $\left(\mathrm{mg} \mathrm{kg}^{-1}\right)$, and $k_{1}$ is the first-order constant of sorption kinetics $\left(\mathrm{h}^{-1}\right)$. Greater values of $Q_{e}$ and smaller values of $k_{1}$ indicate larger $P$ sorption capacity and reaction rate of sorption kinetics, respectively. Pearson correlation coefficients, at confidence levels of $95 \%$ ( $p$ $<0.05)$ and $99 \%(p<0.01)$, were used to analyze the correlation between $\mathrm{P}$ adsorption isotherms and fractional composition.

\section{RESULTS}

Spatial Patterns of P Concentration in Water of River Networks. Water quality parameters showed variability across the river networks during the four-season sampling campaigns (Table S3 in the SI). The seasonal mean concentrations of total phosphorus in water were in the range of $0.23-0.33 \mathrm{mg} \mathrm{L}^{-1}$, presenting spatial variability with flow pathways. As shown in Figure S4 in the SI, the concentration of total phosphorus is high in the upstream (Sites J3, D4; B4, B5, N4, N5) together with high concentrations of total suspended solids caused by strong resuspension of sediments, which decreased toward midstream due to particles settling along the flow direction (Figure S2 in the SI). The concentration of total phosphorus increased in the downstream after flowing through highly urbanized areas of Changzhou City and Yixing City, as shown in the sampling sites of $\mathrm{J} 3, \mathrm{~W} 1-\mathrm{W} 2, \mathrm{X} 1-\mathrm{X} 4, \mathrm{Y} 1$, and $\mathrm{Y} 2$, indicating the impacts by point source pollution.

The concentrations of total phosphorus, having an average of $0.2 \mathrm{mg} \mathrm{L}^{-1}$ at the 13 concentrated inflowing river mouths (I1I13), showed minimal seasonal variation with discharge (Figure 2 ), whereas the monthly variation of total nitrogen matched

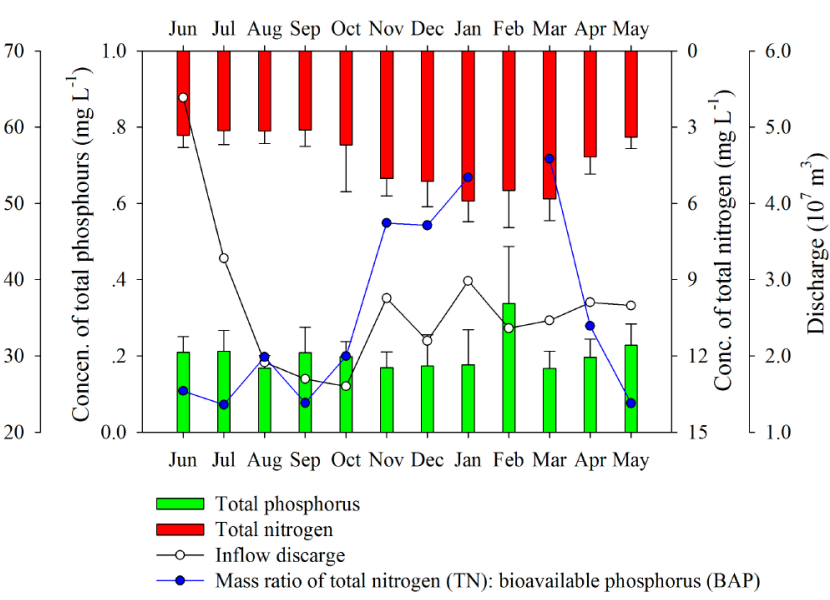

Figure 2. Concentrations of total phosphorus, total nitrogen, and discharge in the concentrated inflowing rivers through the Huxi part during the period from June 2015 to May 2016. (Monthly data of discharge in the Huxi part at the end of each month was collected from open access reports at the official Web site of the Taihu Basin Authority http://www.tba.gov.cn; monthly variation of total nitrogen was cited from our previous work, Yi et al. ${ }^{20}$ Bioavailable phosphorus in the inflowing rivers is estimated to be $60 \%$ of total phosphorus on average, according to the proportion of $\mathrm{NH}_{4} \mathrm{Cl}-\mathrm{P}$ plus BD-P and $\mathrm{NaOH}-\mathrm{P}$ in Ext-TP of sediments at the west site. Mass ratio of total nitrogen (TN): bioavailable phosphorus (BAP) in February of 2016 was not calculated because of the high concentration of total phosphorus in several inflowing rivers during this sampling campaign.)

well with the hydrological rhythm of the basin, which was well presented in the previous work. ${ }^{20}$ During high flow in summer, the lowest total nitrogen concentration of $2.9 \mathrm{mg} \mathrm{L}^{-1}$ on average occurred due to storm runoff dilution, with nonpoint sources from fertilizer/soils and atmospheric deposition constituting the highest proportion of the total nitrogen load. During low flow in winter, the average concentration of total nitrogen increased to $5.7 \mathrm{mg} \mathrm{L}^{-1}$ with an increased proportion of point sources from sewage/manure.

Spatial Patterns of $\mathrm{P}$ Concentration and Fractionation in Sediment. The total extractable P (Ext-TP) exhibited great variation across the basin, with a range of $390.8-1826.7 \mathrm{mg}$ $\mathrm{kg}^{-1}$ (Table S4 in the SI). The largest percentages of Ext-TP were in acid-soluble forms ( $\mathrm{HCl}-\mathrm{P})$ and the fraction associated with amorphous hydroxides $\left(\mathrm{NaOH}_{25}-\mathrm{P}\right)$, accounting for $33.8 \%$ and $31.8 \%$ of Ext-TP on average across all sampling sites, respectively. They were followed by the $\mathrm{P}$ fraction associated with reducible metal hydroxides (BD-P), which accounted for $19.2 \%$. The residual $\mathrm{P}$, denoted as the $\mathrm{NaOH}_{85}-\mathrm{P}$ fraction, was $9.0 \%$ of Ext-TP, and the ion-exchangeable forms $\left(\mathrm{NH}_{4} \mathrm{Cl}-\mathrm{P}\right)$ had the lowest proportion of Ext-TP, only $0.7 \%$ on average.

Similar to the spatial distribution of total phosphorus in the water column, the sediment $\mathrm{P}$ concentration increased from the upstream toward the lake. The most heavily polluted river networks, where Ext-TP concentrations were over $1000 \mathrm{mg}$ $\mathrm{kg}^{-1}$, were located in the littoral areas such as Changzhou City and Yixing City (Figure 1, Figure S5 in the SI). The HCl-P was the predominant fraction in the upstream rivers, accounting for 69.0\% of Ext-TP in the Danjinlicaohe River (D1-D4). The proportion of $\mathrm{NaOH}_{25}-\mathrm{P}$ and BD-P increased toward the middownstream river networks, accounting for $70.0 \%$ of Ext-TP. The BD-P proportion was higher in the downstream, and the $\mathrm{NaOH}_{25}-\mathrm{P}$ proportion was higher in midstream (Figure 3 ). 


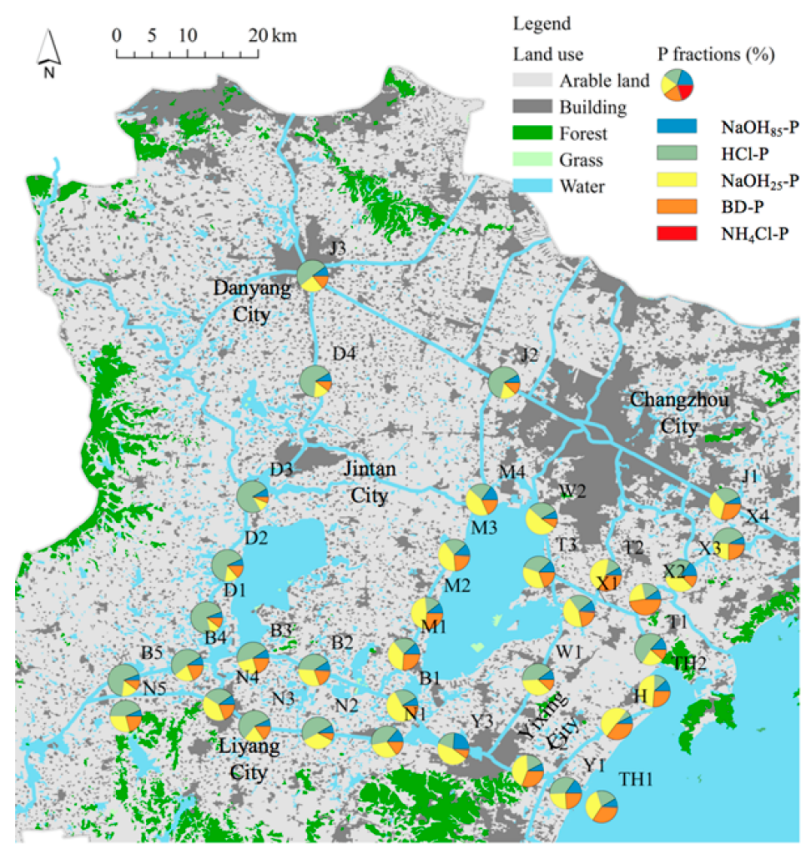

Figure 3. Spatial distribution of $\mathrm{P}$ fractionation of sediments in the inflowing river networks of Lake Taihu.

Phosphorus Sorption on Sediments Related to Its Fractionation. Most isotherms were highly linear $(p<0.01)$, and the values of $k_{\mathrm{e}}, E P C_{0}$, and NAP showed spatial variations, with ranges of $30.2-348.6 \mathrm{~L} \mathrm{~kg}^{-1}, 0.03-1.73 \mathrm{mg} \mathrm{L}^{-1}$, and $8.2-$ $75.9 \mathrm{mg} \mathrm{kg}^{-1}$, respectively (Figure S6 in the SI). The Pearson correlation between $\mathrm{P}$ fraction compositions showed Ext-TP was positively correlated to $\mathrm{NH}_{4} \mathrm{Cl}-\mathrm{P}, \mathrm{BD}-\mathrm{P}$, and $\mathrm{NaOH}-\mathrm{P}$, indicating that the increased Ext-TP concentration of sediment in the basin was attributable to $\mathrm{P}$ adsorption on iron and aluminum oxides rather than calcium compounds (Table S5 in the SI). This was consistent with the spatial patterns of $\mathrm{P}$ fractions, with increased proportions of $\mathrm{BD}-\mathrm{P}$ and $\mathrm{NaOH}_{25} \mathrm{-P}$ in sediments from upstream to mid-downstream river networks (Figures S4 and S5 in the SI). Furthermore, the P sorption ability of sediments, characterized by $k_{\mathrm{e}}$, was positively correlated to oxidizable matter and activated fractions of BD$\mathrm{P}, \mathrm{NaOH}_{25}-\mathrm{P}$, and $\mathrm{NaOH}_{85}-\mathrm{P}$; but it was negatively correlated to inert HCl-P forms $(p<0.01$ or $p<0.05)$. Strongly positive correlation between $k_{\mathrm{e}}$ values and oxidizable matter was observed, indicating that organic matter could play an important role in P sorption behaviors.

Phosphorus Accumulation in Lake Sediments and Connections to Transport in River Networks. The sediment $\mathrm{P}$ distribution exhibited marked differences between the west site (inflow area) and the east site (outflow area) of Lake Taihu (Figure 4). The concentrations of sediment Ext-TP at the west site increased from $300.5 \mathrm{mg} \mathrm{kg}^{-1}$ at $20 \mathrm{~cm}$ depth to $586.4 \mathrm{mg} \mathrm{kg}^{-1}$ at the surface along the sediment core, reflecting rapid $\mathrm{P}$ accumulation with the eutrophication process of Lake Taihu in past decades. The concentrations of sediment Ext-TP were stable at the east site, with an average of $318.3 \mathrm{mg} \mathrm{kg}^{-1}$ along the sediment core, due to lower $\mathrm{P}$ sedimentation in outflow areas covered by macrophytes. Fractions of BD-P, $\mathrm{NaOH}_{25}-\mathrm{P}$, and HCl-P at the west site increased from the bottom to the surface at 38.1-187.1, 98.1-172.2, and 125.2$170.7 \mathrm{mg} \mathrm{kg}^{-1}$, respectively. HCl-P was the dominant fraction at the east site, and the $\mathrm{P}$ fractional composition was less

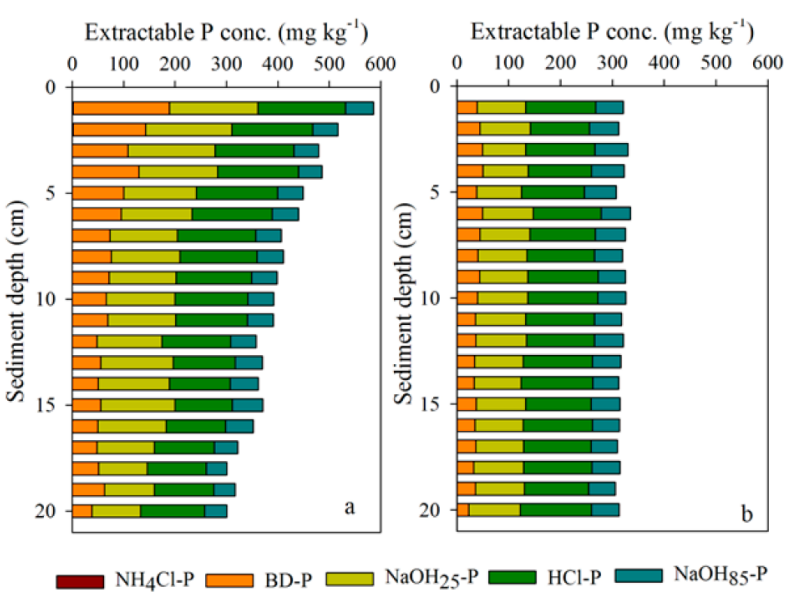

Figure 4. Sediment $\mathrm{P}$ fractional composition at the west site (a) and east site (b) in Lake Taihu.

changeable with depth. The $\mathrm{P}$ fractional composition of surface sediment in the west lake was similar to that in the middownstream of the river networks, where BD-P and $\mathrm{NaOH}_{25}-\mathrm{P}$ were predominant fractions, indicating that $\mathrm{P}$ transport from the river networks to the lake occurred mainly in bioavailable forms.

The transport processes were further clarified and verified through experiments by characterizing $\mathrm{P}$ fractionation and adsorption behaviors with size-sieved particles, sorted by sediment resuspension due to hydrodynamic disturbance from canal navigation in the river networks. The $\mathrm{P}$ was enriched toward fine particles, as the Ext-TP concentrations increased from $420.8 \mathrm{mg} \mathrm{kg}^{-1}$ in the particle size group of 50$150 \mu \mathrm{m}$ to $1220.9 \mathrm{mg} \mathrm{kg}^{-1}$ in the particle size group of $<5 \mu \mathrm{m}$ (Figure 5). The HCl-P concentration dropped down with the

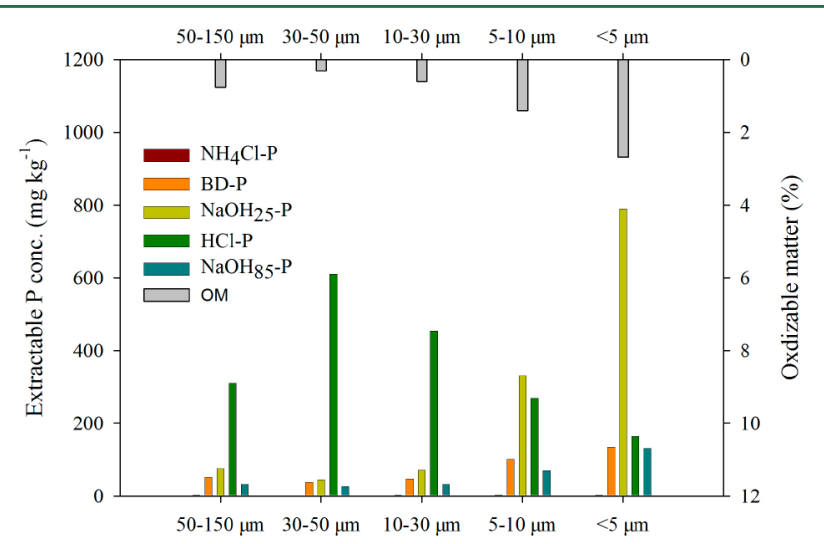

Figure 5. Sediment $\mathrm{P}$ fractionation with particle size distribution at Site J2 of the Beijing-Hangzhou Grand Canal. (Note: OM is the oxidizable matter in different groups of particles; each bar shows the average values for triplicate sediment samples.)

decrease of particle size, while the concentrations of BD-P, $\mathrm{NaOH}_{25}-\mathrm{P}$, and $\mathrm{NaOH}_{85}-\mathrm{P}$ fractions increased with the decrease of particle size. According to particle size analysis for all samples of suspended solids collected across the river networks, particles with grain size smaller than $30 \mu \mathrm{m}$ were dominant (Figure S7 in the SI). The suspended solids tended to transport to the lake, with enriched $\mathrm{NaOH}_{25}-\mathrm{P}$ and $\mathrm{NaOH}_{85}{ }^{-}$ $\mathrm{P}$ in the particle groups of $5-10 \mu \mathrm{m}$ and $<5 \mu \mathrm{m}$. 
Fine particles $(<10 \mu \mathrm{m})$ showed larger sorption capacity, with $Q_{\mathrm{e}}$ values of $23.3 \mathrm{mg} \mathrm{kg}^{-1}$ for the size group of 5-10 $\mu \mathrm{m}$ particles and $36.6 \mathrm{mg} \mathrm{kg}^{-1}$ for the size group of $<5 \mu \mathrm{m}$ particles (Figure 6a). These two size groups of particles also had smaller
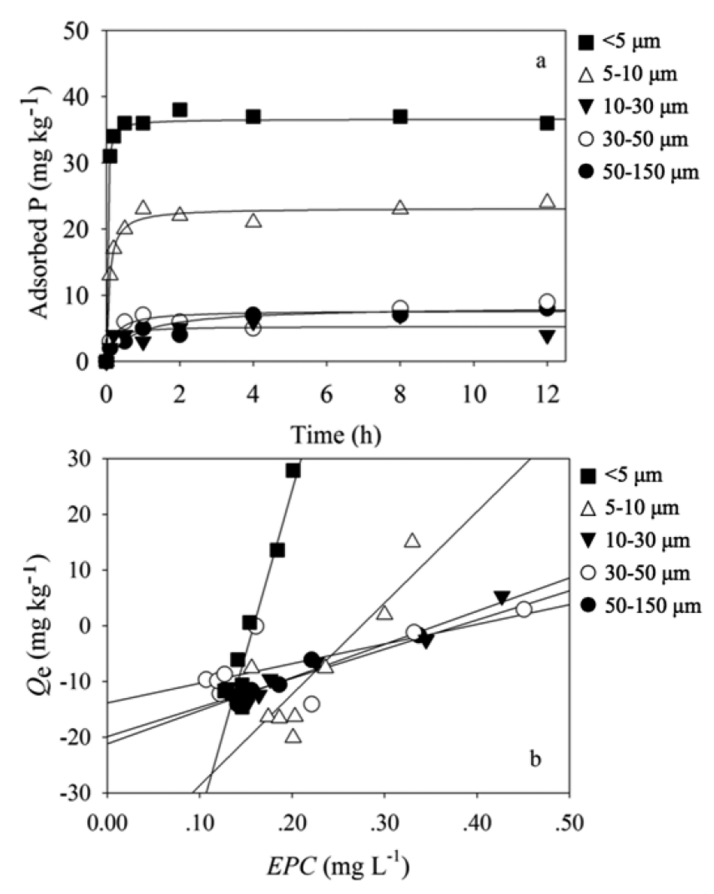

Figure 6. Sorption kinetics (a) and adsorption isotherms (b) of $\mathrm{P}$ on sediments with particle size distribution in the Beijing-Hangzhou Grand Canal. (Note: each straight line indicates a result from a singlesediment sample with size differences; results for sorption kinetics; adsorption isotherms and sediment fractions (Figure 5) were remarkably consistent.)

first-order sorption constant values, with $k_{1}$ values of 0.017 and $0.075 \mathrm{~h}^{-1}$ for the size groups of $<5 \mu \mathrm{m}$ and $5-10 \mu \mathrm{m}$ particles, respectively. The other groups of coarser particles showed lower $\mathrm{P}$ sorption ability, with smaller $Q_{\mathrm{e}}$ values and larger $k_{1}$ values.

Adsorption isotherms also varied with particle size distribution (Figure 6b). Consistent with the sorption kinetics, fine particles of 5-10 $\mu \mathrm{m}$ and $<5 \mu \mathrm{m}$ had higher $\mathrm{P}$ binding energy and lower equilibrium $\mathrm{P}$ concentration at zero sorption, with $k_{\mathrm{e}}$ values of 164.0 and $584.7 \mathrm{~kg} \mathrm{~L}^{-1}$ and $E P C_{0}$ values of 0.27 and $0.16 \mathrm{mg} \mathrm{L}^{-1}$, respectively. The $k_{\mathrm{e}}$ and $E P C_{0}$ of the other groups of coarser particles were in the ranges of 35.0$59.9 \mathrm{~kg} \mathrm{~L}^{-1}$ and $0.36-0.39 \mathrm{mg} \mathrm{L}^{-1}$.

\section{DISCUSSION}

Phosphorus Redistribution and Transport from River Networks to the Lake. The potential for sediment P release has received great attention because of the impacts on the restoration of eutrophic lakes. ${ }^{9,29}$ However, reductions of external P load undoubtedly have priority. At the basin scale, spatial patterns of $\mathrm{P}$ could indicate the relative importance of different pollution sources, such as point sources versus nonpoint sources. The upstream river networks located in agricultural areas presented lower concentrations of total phosphorus in the water column and sediments derived mainly from nonpoint sources, whereas the downstream river networks showed higher $\mathrm{P}$ pollution impacted mainly by point sources from urbanized areas.
The fractional composition of sediment $\mathrm{P}$ could provide more details on $\mathrm{P}$ environmental indicators. Previous studies revealed that fine particles are selectively eroded from the soil surface and easily transported downstream and exhibit preferential export of nonapatite $\mathrm{P}\left(\mathrm{NaOH}_{25}-\mathrm{P}, \mathrm{BD}-\mathrm{P}\right.$, and $\mathrm{NaOH}_{85}-\mathrm{P}$ ), resulting in higher proportions of labile or bioavailable forms of inorganic-P in lakes or rivers related to the basin soils. ${ }^{30,31}$ This could partially explain the spatial patterns of sediment $\mathrm{P}$ fractionation in the river networks across the Lake Taihu basin, where the fraction of HCl-P was predominant in the upstream. In the upstream areas of agriculture, soil erosion could also be important to the load of coarse particles with a short transport pathway or due to bank failure, ${ }^{31,32}$ resulting in a higher proportion of $\mathrm{HCl}-\mathrm{P}$ from nonpoint sources. In the mid-downstream of urbanized areas, the results indicated increased $\mathrm{P}$ adsorption from point sources on $\mathrm{Fe}$-oxides and $\mathrm{Al}$--oxides of sediments. Therefore, significant correlation occurred between $\mathrm{P}$ concentration, fraction, and adsorption parameters across the sampling sites in the basin (Table S5 in the SI).

Hydrological and hydrodynamic conditions could greatly affect $\mathrm{P}$ transformation and transport in rivers, lakes, and littoral areas, which has been extensively discussed. ${ }^{33-38}$ Hydrodynamic disturbances can cause direct release of soluble reactive $P$ from sediments and resuspension of particulate $\mathrm{P} .{ }^{17,37}$ The $\mathrm{P}$ liberated from sediment could be resorbed and immobilized by particles in the subsequent resettling process, probably linked to the formation of amorphous oxides or inert forms. ${ }^{15,39}$ However, this explanation is speculative since it is usually based on the weakly discernible changes in P fractional composition during suspension and settling periods.

In this study, the $\mathrm{P}$ redistribution with suspension processes could be clarified according to the adsorption behaviors on particles sorted by hydrodynamics. The canals are mostly narrow and shallow; therefore, the propellers of ships caused strong disturbance of the sediment and suspended particles of different grain sizes. Coarse particles could settle down in a few minutes, while fine particles could travel hours to days within the unsteady flow in the canals. This process could act as a "sieve" for size-grouped particles. When sediment disturbances from, for example, ship navigation occurred, the highly concentrated $\mathrm{P}$ in pore water of anoxic sediments could immediately release into the water column. During the resorption process, $\mathrm{P}$ could be redistributed by competition between particles of different sizes. More portions were adsorbed in fine particles, characterized by adsorption isotherms and sorption kinetics of larger sorption capacity, stronger P-binding energy, shorter sorption time, and lower equilibrium concentration. The stronger sorption ability of fine particles was attributed to their larger surface/volume ratio, enriched metal oxides, and bound organic matters with more sorption affinity for P (Figure 5). The resorption process could reach completion in several minutes for the size groups of $<5$ $\mu \mathrm{m}$ and $5-10 \mu \mathrm{m}$ particles.

Resuspension occurred year round with the strong and frequent hydrodynamic disturbance in the canals, generating consistent mixing of particles. Under the small magnitude of flow velocity across the river networks (Figure S2 in the SI), only the fine particles have great potential to transport to the downstream (Figure S7 in the SI), traveling hours to days before reaching the lake. Consequently, transport of particles and their associated $\mathrm{P}$ to the lake has minimal seasonal variation due to the seasonal discharge regimes in the basin and the fine 
particles (Figure 2 and Figure S8 in the SI), while phosphorus loading increased from upstream to downstream because of more discharge of point sources from intensified urbanization, leading to further enrichment of $\mathrm{P}$ on fine particles with more bioavailable forms along the flow pathways. Therefore, a high concentration of $\mathrm{P}$ in surface water and sediments occurred in the downstream rivers of Changzhou City and Yixing City, such as the Xilicaohe River, Wuyiyunhe River, Taigeyunhe River, and the downstream sections of the Yilihe River (Figure 3, Figures S4 and S5 in the SI). These processes could act as a kind of P sieving related to hydrodynamics and particle transport in the river networks.

After entering into the lakes, most of the fine particles enriched with BD-P and $\mathrm{NaOH}_{25}-\mathrm{P}$ settled in the west part of Lake Taihu rather than being transported to the east part of the lake. Furthermore, settled $\mathrm{P}$ in the west lake could be recycled more efficiently, controlled by biological processes in the lake. For example, the BD-P in the lake was greatly influenced by redox conditions favoring $P$ release. ${ }^{9,39}$ In the west part of the lake, anoxic conditions in subsurface sediments could result in $\mathrm{P}$ liberation from the BD-P fraction, moving toward the surface sediments and being resorbed by $\mathrm{Fe}$-oxides, ${ }^{28}$ leading to BD-P accumulation and the distribution profile shown in Figure 4a.

Implications for $\mathbf{P}$ Management and Ecological Restoration from Basin to Lake. Recent studies indicated that the algal growth in Lake Taihu shifts from $\mathrm{P}$ limitation in winter-spring to $\mathrm{N}$ limitation in cyanobacteria-dominated summer-fall and that reduction of both $\mathrm{N}$ and $\mathrm{P}$ loads must be conducted. $^{20,40-42}$ The limitation patterns of algae growth correspond well to nutrient loading patterns from the basin. Lower $\mathrm{N}$ concentrations in the inflow occurred during summer-fall seasons due to storm runoff (Figure 2), with a low average mass ratio of total nitrogen:bioavailable phosphorus of 25:1. When denitrification was simultaneously enhanced due to high temperature, it further reduced the $\mathrm{N}$ concentration in the lake. The particulate P could be resuspended by strong wind-induced hydraulic disturbance in the shallow lake. ${ }^{14,38}$ The anoxia incurred by decomposition of dead algae accumulated in sediments in the eutrophic lake during warmer seasons would stimulate $\mathrm{P}$ release from the $\mathrm{BD}-\mathrm{P}$ fraction. Meanwhile, elevated $\mathrm{pH}$ in the sediment-water interface created by intense photosynthesis during algal blooms would induce massive $\mathrm{P}$ release from the $\mathrm{NaOH}_{25} \mathrm{P}$ fraction in the shallow lake. ${ }^{43,44}$ These processes jointly lead to $\mathrm{N}$ instead of $\mathrm{P}$ limitation during summer-fall seasons, with the mass ratio of total nitrogen:total phosphorus (N:P) declining to below 20:1 in the lake. ${ }^{40}$ During winter-spring, inflow with high $\mathrm{N}$ concentration and low discharge occurred, while $\mathrm{P}$ tended to deposit toward the bottom with dead algae, leading to seasonal $\mathrm{P}$ limitation, corresponding to high mass ratios of $\mathrm{N}: \mathrm{P}$ in the inflow (Figure 2) and the lake as well. In addition, more emphasis on $\mathrm{P}$ management by reducing $\mathrm{P}$ availability, together with restriction of carbon sources for denitrification in recent decades, has promoted the relative accumulation of $\mathrm{N}$ in lakes, resulting in arguments for removal of both $\mathrm{N}$ and $\mathrm{P}$ loads. ${ }^{45} \mathrm{In}$ the outflow of Lake Taihu, the annual average concentrations of $1.2 \mathrm{mg} \mathrm{L}^{-1}$ total nitrogen and $0.04 \mathrm{mg} \mathrm{L}^{-1}$ total phosphorus (data in 2012-2013) indicated the important role of denitrification in decreasing the $\mathrm{N}: \mathrm{P}$ ratio $(30: 1)$ for the eutrophic lake with algae biomass accumulation and a hydraulic retention time of one-half a year.

Nitrogen reduction is a great challenge due to its heavy load both from point sources and nonpoint sources in the developed
Lake Taihu basin. ${ }^{20}$ However, the $\mathrm{P}$ reduction goal is also quite ambitious according to this research, considering the $\mathrm{P}$ spatial patterns in the basin, transport and redistribution in the river networks, and recycling in the lake. The primary action is to substantially reduce the external $\mathrm{P}$ load from point sources, which accounted for around a 50\% proportion of the total phosphorus load in the Lake Taihu basin. ${ }^{46}$ Phosphorus reduction in mid-downstream urbanized areas (Changzhou City and Yixing City) is essential, where high P concentrations in surface water and sediment occurred in bioavailable forms (Figure 3, Figures S4 and S5 in the SI).

With respect to controlling the potential for sediment $\mathrm{P}$ release, remediation techniques, such as $\mathrm{P}$ inactivation agents, algae harvesting, and microbiological recovery, could have a very limited effect or be unrealistic in practice. However, the comparison of $\mathrm{P}$ distribution in sediment cores sampled at the west and east sites indicated that aquatic macrophytes could play important roles in the immobilization of $\mathrm{P}$ by resisting particle resuspension and reducing the $\mathrm{P}$ cycling rate. The hydrodynamics in the shallow Lake Taihu is characterized by wind-induced currents, causing significant sediment resuspension and $\mathrm{P}$ release and nutrient diffusion. ${ }^{14,47,48}$ Recent research indicated that the spatial distribution of suspended solids and particulate $\mathrm{P}$ forms was consistent with wind waves and lake currents. ${ }^{49,50}$ More sediment $\mathrm{P}$ accumulated in the southwest areas and the hyper-eutrophic bays of the north part, where aquatic vegetation is sparse; whereas $P$ accumulation was less in the east areas, where aquatic vegetation is abundant. ${ }^{51}$ Primarily, the presence of aquatic vegetation reduced sediment resuspension by attenuating wave, current energy, and bed shear stress. ${ }^{52}$ In addition, the nutrient recycling rate could decrease within the areas of vegetation compared to the open water areas with dominance of algae. ${ }^{53}$ Moreover, the high $\mathrm{HCl}-\mathrm{P}$ fraction at the east site could be attributed to the calcareous terrain of the recharge area, whereas $\mathrm{P}$ at the west site was mainly of anthropogenic origin from upstream areas, with more bioavailable forms. This suggests that great efforts should be taken toward the restoration of aquatic vegetation coverage in the southwest areas and the hyper-eutrophic bays in the north of Lake Taihu, which have largely decreased in the last decades due to progressive eutrophication.

\section{ASSOCIATED CONTENT}

\section{Supporting Information}

The Supporting Information is available free of charge on the ACS Publications website at DOI: 10.1021/acs.est.7b02710.

Methods for water sampling and analysis, adsorption isotherms and sorption kinetics of phosphorus; list of rivers and sampling sites; water balance in Lake Taihu and the study area; statistics of water quality, extractable total phosphorus and its fractional composition; matrix of Pearson correlation coefficients for $\mathrm{P}$ adsorption isotherms and fractional composition; water regime and water flow regime in 2014; spatial patterns for total phosphorus in surface water and sediments; cumulative percentage distribution for $k_{\mathrm{e}}, E P C_{0}$, and $N A P$ in $\mathrm{P}$ adsorption isotherms; gravity-settling column used for separation and collection of particles; cumulative percentage distribution for median grain size of particles in samples of suspended solids; concentrations of total suspended solids in the concentrated inflowing rivers through the Huxi part (PDF) 


\section{AUTHOR INFORMATION}

\section{Corresponding Author}

*Tel./Fax: +86 25 85829765. E-mail: qwchen@nhri.cn. ORCID $\odot$

Qiuwen Chen: 0000-0003-0905-7591

\section{Notes}

The authors declare no competing financial interest.

\section{ACKNOWLEDGMENTS}

This research was supported by the National Nature Science Foundation of China (Nos. 91547206 and 51425902) and Jiangsu Water Resources Department (No. 2016021). The authors are grateful to Dr. Xijun Lai for calculating the flow regime across the river networks of the Lake Taihu basin and Dr. Catherine Rice for proofreading the manuscript.

\section{REFERENCES}

(1) Elser, J.; Bennett, E. Phosphorus cycle: A broken biogeochemical cycle. Nature 2011, 478 (7367), 29-31.

(2) Mort, H. P.; Slomp, C. P.; Gustafsson, B. G.; Andersen, T. J. Phosphorus recycling and burial in Baltic Sea sediments with contrasting redox conditions. Geochim. Cosmochim. Acta 2010, 74 (4), 1350-1362.

(3) Lovley, D. R. Microbial $\mathrm{Fe}(\mathrm{III})$ reduction in subsurface environments. FEMS Microbiol. Rev. 1997, 20 (3-4), 305-313.

(4) Roden, E. E.; Wetzel, R. G. Kinetics of microbial Fe(III) oxide reduction in freshwater wetland sediments. Limnol. Oceanogr. 2002, 47 (1), 198-211.

(5) Mortimer, C. H. The exchange of dissolved substances between mud and water in lakes. J. Ecol. 1941, 29 (2), 280-329.

(6) Rydin, E.; Huser, B.; Welch, E. B. Amount of phosphorus inactivated by alum treatments in Washington lakes. Limnol. Oceanogr. 2000, 45 (1), 226-230.

(7) Kopáček, J.; Borovec, J.; Hejzlar, J.; Ulrich, K. U.; Norton, S. A.; Amirbahman, A. Aluminum control of phosphorus sorption by lake sediments. Environ. Sci. Technol. 2005, 39 (22), 8784-8789.

(8) Reitzel, K.; Hansen, J.; Andersen, F.Ø.; Hansen, K. S.; Jensen, H. $S$. Lake restoration by dosing aluminum relative to mobile phosphorus in the sediment. Environ. Sci. Technol. 2005, 39 (11), 4134-4140.

(9) Huser, B. J.; Egemose, S.; Harper, H.; Hupfer, M.; Jensen, H.; Pilgrim, K. M.; Reitzel, K.; Rydin, E.; Futter, M. Longevity and effectiveness of aluminum addition to reduce sediment phosphorus release and restore lake water quality. Water Res. 2016, 97, 122-132.

(10) Koschel, R.; Benndorf, J.; Proft, G.; Recknagel, F. Calcite precipitation as a natural control mechanism of eutrophication. Arch. Hydrobiol. 1983, 98 (3), 380-408.

(11) Dittrich, M.; Gabriel, O.; Rutzen, C.; Koschel, R. Lake restoration by hypolimnetic $\mathrm{Ca}(\mathrm{OH})_{2}$ treatment: impact on phosphorus sedimentation and release from sediment. Sci. Total Environ. 2011, 409 (8), 1504-1515.

(12) Yang, Y. H.; Wang, G. Y.; Guo, H. C.; Sheng, H.; Zhou, F. An integrated SOM-based multivariate approach for spatio-temporal patterns identification and source apportionment of pollution in complex river network. Environ. Pollut. 2012, 168 (5), 71-79.

(13) Zhao, H. X.; Duan, X. J.; Stewart, B.; You, B. S.; Jiang, X. W. Spatial correlations between urbanization and river water pollution in the heavily polluted area of Taihu Lake Basin, China. J. Geogr. Sci. 2013, 23 (4), 735-752.

(14) Qin, B. Q.; Hu, W. P.; Gao, G.; Luo, L. C.; Zhang, J. S. Dynamics of sediment resuspension and the conceptual schema of nutrient release in the large shallow Lake Taihu, China. Chin. Sci. Bull. 2004, 49 (1), 54-64.

(15) Li, D. P.; Huang, Y. Sedimentary phosphorus fractions and bioavailability as influenced by repeated sediment resuspension. Ecol. Eng. 2010, 36 (7), 958-962.
(16) Wildman, R. A., Jr; Hering, J. G. Potential for release of sediment phosphorus to Lake Powell (Utah and Arizona) due to sediment resuspension during low water level. Lake Reservoir Manage. 2011, 27 (4), 365-375.

(17) Tammeorg, O.; Horppila, J.; Laugaste, R.; Haldna, M.; Niemisto, J. Importance of diffusion and resuspension for phosphorus cycling during the growing season in large, shallow Lake Peipsi. Hydrobiologia 2015, 760 (1), 133-144.

(18) Kleeberg, A.; Herzog, C. Sediment microstructure and resuspension behavior depend on each other. Biogeochemistry 2014, 119 (1), 199-213.

(19) Morgan, B.; Rate, A. W.; Burton, E. D. Water chemistry and nutrient release during the resuspension of FeS-rich sediments in a eutrophic estuarine system. Sci. Total Environ. 2012, 432 (16), 47-56.

(20) Yi, Q. T.; Chen, Q. W.; Hu, L. M.; Shi, W. Q. Tracking nitrogen sources, transformation, and transport at a basin scale with complex plain river networks. Environ. Sci. Technol. 2017, 51 (10), 5396-5403.

(21) Standard Methods for the Examination of Water and Wastewater, 16th ed.; APHA, AWWA, WPCF: Washington D.C., 1998.

(22) Tan, K. H. Soil Sampling, Preparation and Analysis; Marcel Dekker: New York, 1995.

(23) Psenner, R.; Boström, B.; Dinka, M.; Pettersson, K.; Puckso, R.; Sager, M. Fractionation of phosphorus in suspended matter and sediment. Ergeb. Limnol. 1988, 30, 98-113.

(24) Hupfer, M.; Gächter, R.; Giovanoli, R. Transformation of phosphorus species in settling seston and during early sediment diagenesis. Aquat. Sci. 1995, 57 (4), 305-324.

(25) Lake, B. A.; Coolidge, K. M.; Norton, S. A.; Amirbahman, A. Factors contributing to the internal loading of phosphorus from anoxic sediments in six Maine lakes, USA. Sci. Total Environ. 2007, 373, 534541.

(26) Ribeiro, D. C.; Martins, G.; Nogueira, R.; Cruz, J. V.; Brito, A. G. Phosphorus fractionation in volcanic lake sediments (Azores Portugal). Chemosphere 2008, 70 (7), 1256-1263.

(27) Zhou, A. M.; Tang, H. X.; Wang, D. S. Phosphorus adsorption on natural sediments: Modeling and effects of $\mathrm{pH}$ and sediment composition. Water Res. 2005, 39 (7), 1245-1254.

(28) Yi, Q. T.; Xie, K.; Sun, P. F.; Kim, Y. Characterization of phosphorus in the sedimentary environments of inundated agricultural soils around the Huainan Coal Mines, Anhui, China. Sci. Total Environ. 2014, 472, 538-549.

(29) Zamparas, M.; Zacharias, I. Restoration of eutrophic freshwater by managing internal nutrient loads. A review. Sci. Total Environ. 2014, 496, 551-562.

(30) Iglesias, M. L.; Devesa-Rey, R.; Pérez-Moreira, R.; Díaz-Fierros, F.; Barral, M. T. Phosphorus transfer across boundaries: from basin soils to river bed sediments. J. Soils Sediments 2011, 11 (7), 11251134.

(31) Kerr, J. G.; Burford, M. A.; Olley, J. M.; Bunn, S. E.; Udy, J. Examining the link between terrestrial and aquatic phosphorus speciation in a subtropical catchment: The role of selective erosion and transport of fine sediments during storm events. Water Res. 2011, 45 (11), 3331-3340.

(32) Prosser, I. P.; Rutherfurd, I. D.; Olley, J. M.; Young, W. J.; Wallbrink, P. J.; Moran, C. J. Large-scale patterns of erosion and sediment transport in river networks, with examples from Australia. Mar. Freshwater Res. 2001, 52 (5), 81-99.

(33) Stutter, M. I.; Lumsdon, D. G. Interactions of land use and dynamic river conditions on sorption equilibria between benthic sediments and river soluble reactive phosphorus concentrations. Water Res. 2008, 42 (16), 4249-4260.

(34) Cyr, H.; McCabe, K S.K.; Nürnberg, G. K. Phosphorus sorption experiments and the potential for internal phosphorus loading in littoral areas of a stratified lake. Water Res. 2009, 43 (6), 1654-1666.

(35) de Vicente, I.; Cruz-Pizarro, L.; Rueda, F. J. Sediment resuspension in two adjacent shallow coastal lakes: controlling factors and consequences on phosphate dynamics. Aquat. Sci. 2010, 72 (1), 21-31. 
(36) Berretta, C.; Sansalone, J. Hydrologic transport and partitioning of phosphorus fractions. J. Hydrol. 2011, 403 (1), 25-36.

(37) Kleeberg, A.; Hupfer, M.; Gust, G. Quantification of phosphorus entrainment in a lowland river by in situ and laboratory resuspension experiments. Aquat. Sci. 2008, 70 (1), 87-99.

(38) Huang, L.; Fang, H. W.; He, G. J.; Jiang, H. L.; Wang, C. H. Effects of internal loading on phosphorus distribution in the Taihu Lake driven by wind waves and lake currents. Environ. Pollut. 2016, 219, 760-773.

(39) Wang, P. F.; Hu, B.; Wang, C.; Lei, Y. Phosphorus adsorption and sedimentation by suspended sediments from Zhushan Bay, Taihu Lake. Environ. Sci. Pollut. Res. 2015, 22 (5), 6559-6569.

(40) Xu, H.; Paerl, H. W.; Qin, B. Q.; Zhu, G. W.; Gao, G. Nitrogen and phosphorus inputs control phytoplankton growth in eutrophic Lake Taihu, China. Limnol. Oceanogr. 2010, 55 (1), 420-432.

(41) Xu, H.; Paerl, H. W.; Qin, B. Q.; Zhu, G. W.; Hall, N. S.; Wu, Y. Determining critical nutrient thresholds needed to control harmful cyanobacterial blooms in Eutrophic Lake Taihu, China. Environ. Sci. Technol. 2015, 49 (2), 1051-1059.

(42) Paerl, H. W.; Xu, H.; Hall, N. S. Nutrient limitation dynamics examined on a multi-annual scale in Lake Taihu, China: implications for controlling eutrophication and harmful algal blooms. J. Freshwater Ecol. 2015, 30 (1), 5-24.

(43) Xie, L. Q.; Xie, P.; Tang, H. J. Enhancement of dissolved phosphorus release from sediment to lake water by Microcystis blooms-an enclosure experiment in a hyper-eutrophic, subtropical Chinese lake. Environ. Pollut. 2003, 122 (3), 391-399.

(44) Jiang, X.; Jin, X.; Yao, Y.; Li, L.; Wu, F. C. Effects of biological activity, light, temperature and oxygen on phosphorus release processes at the sediment and water interface of Taihu Lake, China. Water Res. 2008, 42 (8), 2251-2259.

(45) Finlay, J. C.; Small, G. E.; Sterner, R. W. Human influences on nitrogen removal in lakes. Science 2013, 342 (6155), 247-250.

(46) Lai, G. Y.; Yu, G.; Gui, F. Preliminary study on assessment of nutrient transport in the Taihu Basin based on SWAT modeling. Sci. China, Ser. D: Earth Sci. 2006, 49 (S1), 135-145.

(47) Hu, C. H.; Hu, W. P.; Zhang, F. B.; Hu, Z. X.; Li, X. H.; Chen, Y. G. Chin. Sci. Bull. 2006, 51 (6), 731-737.

(48) Wu, T. F.; Qin, B. Q.; Zhu, G. W.; Zhu, M. Y.; Li, W.; Luan, C. M. Modeling of turbidity dynamics caused by wind-induced waves and current in the Taihu Lake. Int. J. Sediment Res. 2013, 28 (2), 139-148. (49) Shi, K.; Zhang, Y. L.; Zhu, G. W.; Liu, X. H.; Zhou, Y. Q.; Xu, H.; Qin, B. Q.; Liu, G.; Li, Y. M. Long-term remote monitoring of total suspended matter concentration in Lake Taihu using $250 \mathrm{~m}$ MODISAqua data. Remote Sen. Enviro. 2015, 164 (2), 43-56.

(50) Huang, J.; Xu, Q. J.; Xi, B. D.; Wang, X. X.; Li, W. P.; Gao, G.; Huo, S. L.; Xia, X. F.; Jiang, T. T.; Ji, D. F.; Liu, H. L.; Jia, K. L. Impacts of hydrodynamic disturbance on sediment resuspension, phosphorus and phosphatase release, and cyanobacterial growth in Lake Tai. Environ. Earth Sci. 2015, 74 (5), 3945-3954.

(51) Zhao, D.; Lv, M.; Jiang, H.; Cai, Y.; Xu, D. An S. Spatiotemporal variability of aquatic vegetation in Taihu Lake over the past 30 years. PLoS One 2013, 8 (6), e66365.

(52) Wu, D.; Hua, Z. L. The effect of vegetation on sediment resuspension and phosphorus release under hydrodynamic disturbance in shallow lakes. Ecol. Eng. 2014, 69 (69), 55-62.

(53) Horppila, J.; Nurminen, L. Effects of submerged macrophytes on sediment resuspension and internal phosphorus loading in Lake Hiidenvesi (southern Finland). Water Res. 2003, 37 (18), 4468-4474. 